\title{
An Empirical Assessment of the 1996 Leniency Notice
}

by

\section{Andreas Stephan}

\section{ESRC Centre for Competition Policy and The Norwich Law School, University of East Anglia}

\section{CCP Working Paper 05-10}

\begin{abstract}
Although the 1996 'Notice on the non-imposition or reduction of fines in cartel cases' has been criticised by academics as lacking clarity and certainty, it has been described in European Commission literature as an 'indisputable success' and as having played an 'instrumental role' in uncovering and punishing secret cartels. This paper makes an empirical assessment of horizontal cartel cases in the EC opened as a result of leniency applications under the 1996 notice. Nearly three quarters of the cartels apparently uncovered by this notice were subject to equivalent prior or simultaneous investigations in the U.S. In addition, most of the cartels that were revealed operated in the Chemical industry, were all connected to each other by virtue of the same firms' involvement in more than one cartel, and all failed or ceased to operate before being revealed to the Commission by a cartel member. These two findings would suggest that the 1996 leniency notice was only of limited success in inducing firms to reveal cartels and that most applications for immunity were as a natural consequence of cartels failing and firms looking once more to their own interests rather than those of the cartel. The leniency notice largely succeeded in uncovering failed cartels, not active ones.
\end{abstract}

September 2005

JEL Classification: L13; L41; K21; K40

Keywords: EU, Cartel Policy, Leniency Notice, Chemicals Industry.

Acknowledgements:

I would like to thank the Arts \& Humanities Research Council (UK) for kindly funding my doctoral studies and a special thanks to my supervisor, Prof. Morten Hviid, and to all the members of the Centre for Competition Policy for their conversations and support. The support of the Economic \& Social Research Council (UK) is also gratefully acknowledged.

Contact details:

a.stephan@uea.ac.uk, ESRC Centre for Competition Policy, University of East Anglia, Norwich, NR4 7TJ, UK. www.ccp.uea.ac.uk t: +44 (0) 1603593715

f: + 44(0) 1603591622

ISSN 1745-9648 


\section{Introduction}

The 1996 'Notice on the non-imposition or reduction of fines in cartel cases' (96/C207/04 - henceforth "the 1996 leniency notice") was introduced partly in response to the success of the U.S. Amnesty Program, as reformed in 1993.

The introduction to the 1996 leniency notice states that providing leniency to induce cartel members to reveal their infringements is justified because, "The interests of consumers and citizens in ensuring that such practices are detected and prohibited outweigh the interest in fining those enterprises which cooperate with the Commission, thereby enabling or helping it to detect and prohibit a cartel" (emphasis added). Detection and prohibition are recurring themes in Commission literature concerning the leniency notice. In a 2002 memo answering questions about the notice, the Commission states that "The ultimate objective of this notice is to assist the Commission to unveil cartels and eradicate them" (MEMO/02/23). For the first time, we are in a position to carry out a comprehensive empirical assessment of how successful the 1996 leniency notice was at inducing cartels to reveal. This is because it is only now, 3-4 years after the reformed 2002 leniency notice (2002/C45/03) was introduced, that the Commission decisions involving 1996 leniency notice applications have by and large been delivered, and cases involving 2002 leniency notice applications start being concluded.

The aim of this paper is to determine the extent to which firms who revealed cartels through applications under the 1996 leniency notice were induced to do so by the incentives provided by the notice itself, as opposed to the leniency applications being a natural consequence of the cartels having already failed or being uncovered for other reasons. Part I of the paper assesses what proportion of European leniency notice success is a result of prior or simultaneous success by the U.S. Department of Justice in its investigations and its use of the Amnesty Program. Part II of this paper is a case study outlining how most (apparent) 1996 leniency notice success has concerned closely related cartels in just one industry: Chemicals. Using information primarily contained in the Commission decisions themselves and in industry literature, it is shown that by the time these cartels were revealed to European Commission, they had already failed or ceased to operate either because of market conditions or because of their connection to cartels already under investigation; in particular the Vitamins cartel. 
It is widely recognised that the 1996 leniency notice had certain flaws which limited its effectiveness (e.g. Carle 2002). The main criticisms of the 1996 notice are that it was unclear and uncertain. Its lack of clarity was mainly due to the subjective wording of the notice, in particular stating that an 'instigator' or someone with a 'determining role' could not be granted full or very substantial immunity and that leniency would only be granted if the applicant was the "first to adduce decisive evidence of the cartel's existence". Secondly, there was an inherent lack of certainty as to how a firm would be treated once it had approached the Commission; full or very substantial immunity was not available if the Commission had already opened an investigation into the cartel or already had enough evidence to prove its existence however, applicants had no way of knowing if this was the case. Furthermore, Leniency applicants would only learn of the level of leniency granted when the Commission delivered its final decision, usually several years later.

Despite these criticisms, the Commission still views the 1996 leniency notice as a success. In July 2001, the Competition Commissioner, Mario Monti said, "The Leniency Notice has played an instrumental role in uncovering and punishing secret cartels" (Press Release IP/01/1011). In a 2002 EC Competition Newsletter article announcing the revised leniency notice, the Commission brands the 1996 notice as an "indisputable success" and states that "Statistics data highlight the considerable level of success that the 1996 leniency notice has had... [this] represents a very significant increase of the Commission's anticartel activity" (Arbault \& Pieró 2002). In addition to this, the article emphasises detection as being a central aim of the notice, "it is important that the Commission be in a position to detect a cartel as early as possible".

\section{PART I: Prior and simultaneous U.S. policy success}

If the 1996 leniency notice did indeed play a central role in inducing firms to come forward and reveal cartels, then it is important to rule out other reasons why a cartel member would apply for leniency. As the most serious Article 81 infringements concern international cartels, one of the most important external factors is the policy success of other jurisdictions, in particular the U.S. Department of Justice (henceforth (DOJ'). Most successful EC cartel investigations prompted by leniency applications 
to date have an equivalent U.S. investigation which is either simultaneous to or which precedes that of the European Commission.

Where US investigations precede those of the European Commission, applications under the 1996 leniency notice are a consequence of the cartel being initially cracked either by US investigations or by the US Amnesty Program. Many jurisdictions have to play 'catch-up' with the US, initiating investigations that by and large mirror earlier investigations of the DOJ. This has been helped by increasing cooperation between the DOJ and other competition authorities. Even where US investigations are simultaneous to those of the EC, it is likely that they have played the central role in inducing firms to reveal. This is because for a number of reasons US Cartel policy offers stronger incentives to come forward. Firstly, the DOJ frequently prosecutes individuals in criminal law for their role in the infringement. This means that senior individuals within a company making the decision to collude or reveal, personally stand to lose financially and (more importantly) in terms of their personal freedom. Secondly, the DOJ Amnesty Program provides more certainty than the 1996 leniency notice by, for example, making it possible for immunity to be claimed after an investigation has been opened. Thirdly, it provides anonymity for revealing firms; this means that their identities and any evidence of their role in the infringement are not made available to claimants of private damages by the DOJ (Hewitt Pate 2004). Finally, the US has a plea-bargaining system whereby firms agree to pay certain fines and company directors agree to go to jail for certain lengths of time without the case ever seeing the inside of a court room (other than to approve the plea-bargain). Pleabargaining strengthens the Amnesty Program by providing a quick and certain way for a firm to settle its liability for an infringement, rather than waiting in limbo, overshadowed by the possibility of having fines imposed of an uncertain magnitude. The incentives to reveal are that much stronger in the US that foreign company directors are willing fly to the US of their own volition to serve jail time as part of plea bargains (Hammond 2001) and according to Wils (2005) a number of companies who have colluded in Europe say they would never have colluded in the USA because of fear of the heavy sanctions that would result.

Table 1 below lists thirteen European Commission decisions involving horizontal cartels which have equivalent cases in the US. Unfortunately, due to the secretive nature in which the DOJ operates its Amnesty Program and its plea bargains (in particular the anonymity of revealing firms), it is not possible to determine exactly 
when all their investigations were opened or how. Some, like Lysine, Citric Acid and Vitamins clearly started well before their European counterparts, others like Methylgucamine appear to have started simultaneously in both jurisdictions. However, it is clear from when the first US fine in each case was announced that the US equivalent investigation, in every case, either preceded or was broadly simultaneous to that in Europe.

Table 1 - US-EU parallel investigations

\begin{tabular}{|l|l|l|}
\hline Cartel & $\begin{array}{l}\text { When first U.S. Fine } \\
\text { Announced by DOJ }\end{array}$ & $\begin{array}{l}\text { EU investigation ending in } \\
\text { Commission decision \& fines. }\end{array}$ \\
\hline Amino Acids - Lysine* & Oct-96 & $1996-2000$ \\
\hline Citric Acid & Jan-97 & $1997-2001$ \\
\hline Sodium Gluconate & Sep-97 & $1997-2001$ \\
\hline Graphite Electrodes & Feb-98 & $1997-2001$ \\
\hline Animal Feed Vitamins & May-99 & $1999-2004$ \\
\hline Sorbates & May-99 & $1998-2003$ \\
\hline Vitamins & May-99 & $1999-2001$ \\
\hline Christie's \& Sotheby's & Oct-00 & $\mathbf{2 0 0 0 - 2 0 0 2}$ \\
\hline MCAA Chemicals & Jun-01 & $\mathbf{2 0 0 0 - 2 0 0 5}$ \\
\hline Food Flavour & Aug-01 & $\mathbf{1 9 9 9 - 2 0 0 2}$ \\
\hline Organic Peroxides & Mar-02 & $\mathbf{2 0 0 0 - 2 0 0 3}$ \\
\hline Carbon \& Graphite & Nov-02 & $\mathbf{2 0 0 1 - 2 0 0 3}$ \\
\hline Methylglucamine & Sep-03 & $\mathbf{2 0 0 0 - 2 0 0 2}$ \\
\hline & $\begin{array}{l}\text { * The Methionine and Specialty Graphites cartels, not listed in the table, were both investigated by the } \\
\text { as a direct consequence of the investigations into Amino Acids (Lysine) and Graphite Electrodes. }\end{array}$ \\
\hline
\end{tabular}

To make a more accurate assessment of how successful the 1996 leniency notice was, we must distinguish those leniency cases with a US equivalent. Since the introduction of the 1996 leniency notice in July of that year, 33 Commission decisions have been delivered (to February 2005) involving horizontal cartels ${ }^{1}$, with a total of $€ 3.9$ billion imposed in fines ${ }^{2}$. Of the investigations into those 33 cases, 20 were opened as a result of leniency notice applications, with a total of $€ 2.65$ billion imposed in fines. In 16 of these cases immunity or a leniency discount in excess of $75 \%$ was granted

\footnotetext{
${ }^{1}$ A leniency discount has never been granted in a case primarily involving vertical collusion.

${ }^{2}$ All figures of fines contained in this section are at the levels imposed by the European Commission before appeal to the Court of First Instance and Court of Justice, many of which are still pending.
} 
because a revealing firm satisfied the Section B requirements of the 1996 leniency notice, in particular the requirement that information about the infringement be provided before the Commission had undertaken an investigation or had enough evidence to establish the existence of a cartel. The other five were revealed to the Commission as a result of the leniency notice even though Section B leniency was not awarded. In Amino Acids (2000), the revealing firm (Ajinomoto) was only granted the maximum $50 \%$ discount under Section $\mathrm{D}$ of the notice because it held back documents after coming forward (COMP/36.545/F3 at 412), thus failing to satisfy the requirement that it maintain continuous and complete cooperation throughout the investigation. In Belgian Brewers (2001), the revealing firm, Interbrew, only received a $50 \%$ Section D leniency discount because its determining role in the cartel meant it was not eligible for a higher discount (COMP/37.614/F3 at 356). The French Brewers cartel (2004) did not involve a leniency discount, but was revealed to the Commission through the leniency notice due to Interbrew's cooperation in the Belgian Brewers case (COMP/37.750/B2 at 2). Finally, the Animal Feed Vitamins or Choline Chloride cartel (2004) was revealed through a leniency application by a US supplier called Bioproducts Inc. in 1999. No leniency discount was given because no fine was imposed on the revealing firm (COMP/37.533 at 3).

Table 2 below summarises what proportion of the leniency success (20 cartels punished, $€ 2.65$ billion imposed in fines as result of leniency notice applications), is likely to be on the back of US success given that there is a prior or simultaneous equivalent US investigation.

Table 2 - Proportion of US leniency success (Jul 1996 - Feb 2005)

\begin{tabular}{|c|c|c|c|}
\hline & No of Cases & Fines (€ million) & $\begin{array}{c}\text { Proportion of } \\
\text { Total Fines (\%) }\end{array}$ \\
\hline $\begin{array}{l}\text { Cases Triggered By Leniency } \\
\text { Applications }\end{array}$ & 20 & $\mathbf{2 , 6 5 2}$ & $69.7 \%$ \\
\hline $\begin{array}{c}\text { But where International Cartels with } \\
\text { prior/simultaneous U.S. policy } \\
\text { success }\end{array}$ & $14^{*}$ & 1,961 & $51.6 \%$ \\
\hline EU Only Leniency Investigations & 6 & 691 & $18.1 \%$ \\
\hline
\end{tabular}


If we are to assume that the levels of fines imposed in cartel cases reflect the severity of the infringement, then as much as $74 \%^{3}$ of 1996 leniency notice success in uncovering cartels, may be on the back of the success of DOJ investigations and of the U.S. Amnesty Program. Only a quarter of EC leniency success has been independent of U.S. investigations which means that only about $18 \%$ of total prosecutions in terms of fines imposed have come about as a result of the 1996 leniency notice only.

Under closer scrutiny, there are reasons to believe that even the six 'EU only leniency investigations' did not come about exclusively due to the existence of the leniency notice, despite the fact that U.S. cartel policy is not relevant to them as they operated principally within the EU and members of the European Economic Area. Three of these cartels involved brewers ${ }^{4}$ in the market for beer and were revealed as a result of Interbrew's cooperation with the Commission. The first of these three cartels, Belgian Brewers (2001) had failed in January 1998 as a result of falling demand, overcapacity, pressure from retailers and because the cartel had become too risky (COMP/37.614/F3 at $321 \& 157)$. This last factor may have reflected the presence of the leniency notice, however the fact that the Commission's investigation did not open until the following summer casts doubt over notions that the cartel was 'disrupted' solely by the leniency notice. Similarly the Carbonless Paper cartel (2001) failed in September 1995 because the market for self-copying paper was in decline in the face of new technology (COMP/E-1/36.212 at 430) and the cartel had failed to raise prices. However the revealing firm, Sappi, did not approach the Commission until January 1997, more than two years later. The Needle Cartel (2004), affecting the European market for haberdashery, was revealed by Entaco, the smallest of the three cartel members, whose actions are likely to have been motivated by the fact that Coats, one of the main offenders, had forced Entaco to join the cartel (Press Release IP/04/1313). Finally, the Copper Plumbing cartel (2004), affecting the market for water, heating and gas tubes, was the only case of the six where a cartel member approached the Commission while the cartel was still operating. However the cartel had formed in June 1988 and the revealing firm, Mueler, had only joined the cartel in 1997 and so was not one of the main offenders when it approached the Commission in January 2001.

\footnotetext{
${ }^{3}$ As indicated in Table 2, of the $€ 2,652$ bn imposed in cases triggered by leniency applications, $€ 1,961 \mathrm{bn}$ was imposed in cases involving international cartels with prior/simultaneous US investigations.

${ }^{4}$ Belgian Brewers (2001), Luxembourg Brewers (2001) and French Brewers (2004)
} 


\section{PART II: Cartels in the Chemical Industry Case Study}

While firms may apply for leniency in the EU as a result of investigations in other jurisdictions, namely the US, their decision to come forward and reveal may also be a result of the cartel failing due to the conditions of the market in which it operates. This section looks at the cartels uncovered by the 1996 leniency notice which operated in the chemical industry, looking at reasons why they failed. Table 3 breaks down cartels revealed by 1996 leniency notice applications to date, in terms of the industries in which the cartels operated ${ }^{5}$.

Table 3 - Leniency Success Industry Breakdown (Jul 1996 - Feb 2005)

\begin{tabular}{|l|c|c|c|}
\hline Industry & No of Cartels & Fines (€ million) & Proportion \% \\
\hline Fine Arts & 1 & 20.4 & $0.8 \%$ \\
\hline Chemicals & 11 & $1,778.6$ & $67 \%$ \\
\hline Beer & 3 & 94.6 & $3.6 \%$ \\
\hline $\begin{array}{l}\text { Metals, Carbon \& Metal } \\
\text { Manufacturing }\end{array}$ & 4 & 444.3 & $16.8 \%$ \\
\hline Other Manufacturing & 1 & 313.7 & $11.8 \%$ \\
\hline
\end{tabular}

Table 3 shows that the majority of cartels revealed through the 1996 leniency notice operated in the chemicals industry. Indeed $67 \%$ of leniency success in uncovering

\footnotetext{
${ }^{5}$ This includes only completed cases, where the Commission has delivered its decision.
} 
cartels, in terms of the subsequent fines imposed, involves this industry. To date, there have been 11 Article 81 Commission decisions, involving horizontal cartels in the Chemical industry, which were revealed to the European Commission by leniency applications through the 1996 notice. All eleven are international cartels involving U.S. DOJ equivalent or related investigations.

Significantly, in all eleven cases leniency applications in Europe were made after the cartel ceased to operate due to conditions in the chemical market and due to the close links between the cartels in terms of the firms party to them. In the case of Vitamins, three sub-cartels were still operating but the other six had collapsed. This suggests that the Leniency Notice did not disrupt the cartels, but rather the cartels collapsed for other reasons and thus applications for leniency were a natural consequence of 'leaving the sinking ship' as firms looked to their own interests once more rather than those of the cartel.

The reasons for the cartels failing include overcapacity, new competition from Asia (in particular China), distrust, environmental regulation (Mahdi et al 2002), arbitrage and the unexpected Asia crisis of the late 1990s. Some of these pressures had existed since the 1970s and resulted in extensive mergers, acquisitions and restructuring (Chapman \& Edmond 2000) which made the industry more concentrated in the late 1980s, with collusion more likely as a result - but have also posed a problem to the operation of cartels as the identities and capacities of the players are constantly changing.

Significantly, all 11 cartels can be linked to the Vitamins cartel, by virtue of the fact that a number of firms in the industry were involved in more than one cartel; such is the concentration and diversification of firms in the chemical industry. The Vitamins cartel was the second (after Amino Acids - Lysine) and by far the largest of the 11 cartels to be uncovered. This would suggest that the uncovering of the Vitamins cartel and the resulting investigations (such as dawn raids on firms) might have destabilised the other cartels in the industry as the investigation of one company for its involvement in one cartel might very well uncover its dealings with another. However this does not mean that the leniency notice can claim success through vitamins because the US vitamins investigation preceded that of the European Commission and, as discussed in the next section of this paper, it had largely failed by the time the European investigation was opened. The diagram below illustrates which firms were 
involved in more than one cartel and how that ultimately links all 11 cartels together, with the vitamins cartel being of particular importance. I constructed the diagram while studying the Commission decisions involving these cartels, noting that many firms were addressed by more than one decision. Note the widespread involvement of Aventis S.A. (formerly F.Hoffman-La Roche) and Akzo Nobel in particular.

Figure 4 - Links between cartels in Chemicals Industry

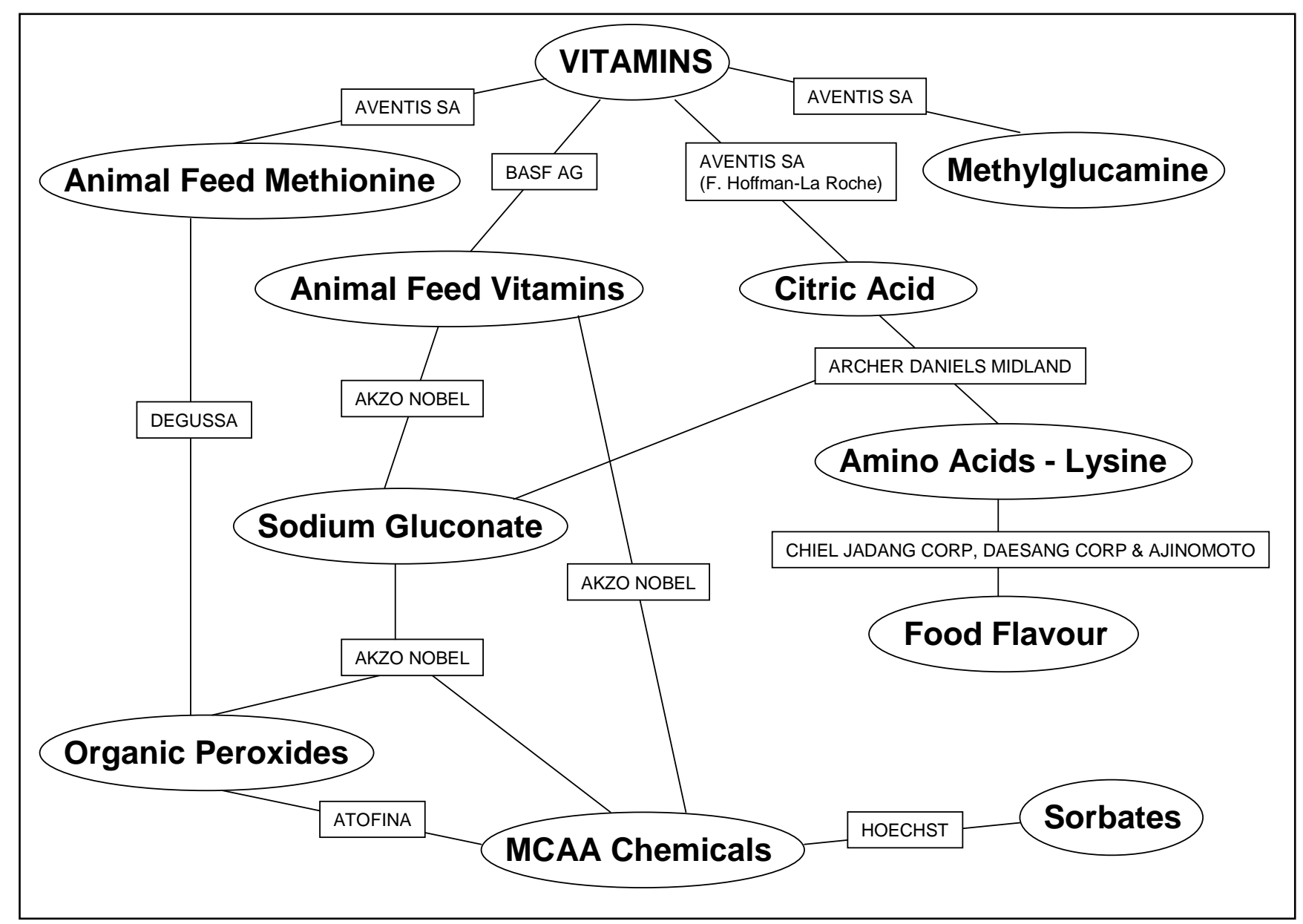

The vitamins cartel actually consisted of nine sub-cartels operating in parallel to each other and involving the same firms. Of these, only three (vitamins A\&E, B5 and D3) were operating when the US DOJ opened its investigations into the vitamins industry in late 1997. The other six had by this time failed. The main reason for their failure was the emergence of new Chinese producers which as early as 1992 were preventing the cartels from reaching their target prices, purportedly going as far as to sell at below production cost in order to break the cartels (COMP/E-1/37.512 at 342). The Vitamin B1 (1991-1994), B6 (1991-1994), C (1991-1995) and Folic Acid (19911994) cartels all failed because Chinese producers (not party to the cartels) increased their capacity in the early 1990s to levels that the cartels could not absorb, and so by 
1995 all five cartels had collapsed as firms were forced to stop colluding and reduce prices to competitive levels. The opening of new and more efficient facilities in China in 1992/3 meant that their costs of production were lower than the cartel producers and their products were of high quality - indeed, one of the cartel members, Takeda C. I. Ltd, noted that it was very hard to recover customers after they started buying from the new Chinese producers (COMP/E-1/37.512 at 253). The speed with which Chinese competition grew in these markets was such that the Chinese share of the vitamin B6 global market increased from 3\% in 1989 to $16 \%$ in 1997 with an interim high of $48 \%$ in 1993 when the cartel was still operating at uncompetitive prices (COMP/E-1/37.512 at 46). In the case of vitamin C, the cartel tried to raise prices by buying up the excess Chinese output but could not keep up with the pace at which Chinese production was increasing (COMP/E-1/37.512 at 448); by 1995 prices of vitamin $\mathrm{C}$ had fallen by a third, forcing the cartel to cease (COMP/E-1/37.512 at 448). In the market for Folic acid, the increased Chinese capacity coincided with a substantial fall in demand in Europe forcing the cartel to disband (COMP/E-1/37.512 at 46). The vitamin B2 (1991-1996) cartel, on the other hand, failed in 1996 when cartel members could not agree on a collusive agreement following arguing and distrust with regard to capacity and the exact details of the agreement. (COMP/E1/37.512 at 490) Similarly, the vitamin $\mathbf{H}$ (1991-1994) cartel failed due to a combination of disagreement and new competition from Korean entrants to the market.

There was an additional factor that placed pressure on the management of the vitamins cartels: this was geographic arbitrage. As the cartels operated globally, the price-fixing process was constantly plagued with problems caused by currency fluctuations. These meant that frequent meetings of the cartel members were necessary in order to make price adjustments in different markets according to currency. The speed of currency fluctuations was such that some of the cartel profits were eroded by brokers in countries experiencing a drop in currency value, exporting vitamins to countries with stronger currencies at prices that were below those fixed by the cartel (Connor 2004). For example, arbitrage problems meant that in 1994 there was a $10 \%$ price gap between Europe and the U.S. for vitamins A \& E (COMP/E$1 / 37.512$ at 223). 
Firstly, the increased concentration of the Chemical Industry in the 1980s made collusion more likely but also made links more likely between the different cartels in terms of firms being involved in more than one collusive agreement. The Methylgucamine (1990-1999) and Animal Feed Methionine (1986-1999) cartels were otherwise successful; reasonably unaffected by competition from China or by the Asia crisis - this was in part due to the strong growth of the poultry industry. The Commission decisions reveal that in 1999 the cartels were not disrupted by the Leniency Notice, but rather by the investigations into the Vitamins cartel (COMP/E2/37.978 at 153). There was a worry amongst members of both cartels that the vitamins investigation would inevitably uncover their collusive agreements mainly because one of the firms under investigation in vitamins, Aventis SA, was also party to both the methylglucamine and methionine cartels (CMR 06/15/98 Vol253 Iss24 P14). These concerns ultimately resulted in Merck KgaA and Aventis SA approaching the Commission and revealing each of the two cartels respectively. Similarly, the decision to end the Animal Feed Vitamins (1994-1998) cartel (involving choline chloride) was strongly influenced by the vitamins investigations and in particular by the fact that BASF AG was under investigation for its involvement in the Vitamins cartels and was also party to Animal Feed Vitamins. Indeed the overlap between firms and different cartels was such that decisions to end cartels might have been driven by close relationships to cartels other than vitamins. As illustrated in Figure 4, three of the firms involved in the Food Flavouring (1989-1998) cartel (involving nucleic acid) were also involved in Amino Acids and Archer Daniels Midland was involved in Amino Acids (1990-1995), Organic Peroxides (1971-1999) and Sodium Gluconate (1987-1995) cartels contemporaneously.

Secondly, the massive export-driven growth of the Chinese chemical industry in the 1990s meant that international cartels (including Vitamins) were undermined by Chinese products flooding the market, causing cartels to collapse well before the investigations into the vitamins cartel were opened. The Citric Acid (1991-1995) cartel (involving one of the most common preservatives) enjoyed healthy demand growth in the early 1990s thanks to strong growth in the European soft drink market. However, this coincided with the emergence of a substantial Chinese citric acid industry which increased its production levels threefold between 1990-1994 (COMP/E-1/36 604 at 35). The Chinese domestic market only accounted for 20\%- 
$25 \%$ of Chinese production and so the rest swamped the global market, helped by low transport costs (COMP/E-1/36 604 at 38). The cartel succeeded in raising prices at first, but this was due to abnormally low prices in 1990 (COMP/E-1/36 604 at 223) and the prices achieved, in any case, were nowhere near the levels reached during the ten years preceding the cartel. Subsequently, the cartel steadily lost control of the market to the Chinese producers as its share dropped from $70 \%$ in 1991 to $52 \%$ in 1994. Attempted concerted practices against the Chinese achieved very little and the cartel members were forced to stop colluding and start competing (COMP/E-1/36 604 at 118). Chinese entry into the citric acid market was so aggressive that Turkey, for example, had to take anti-dumping measures against Chinese citric acid producers between 1995-2000 (COMP/E-1/36 604 at 62).

Thirdly, some cartels suffered from decline, overcapacity and rising costs. For example the extent to which the Sorbates (1978-1996) industry suffered from overcapacity is demonstrated by the exit from the market in 2000 of two major players (Eastman \& Nippon Goeshi). The overcapacity during the late 1990s was estimated at 10,000 tons of Sorbates, with the result that prices were kept low (Jarvis 2000). In the case of the Organic Peroxides (1971-1999) cartel, the market grew steadily throughout the 1990s but overcapacity prevented prices from increasing despite the cartel's existence. Indeed it was only after the cartel ceased that prices began to rise as the industry finally shed some of its overcapacity (Boswell 2000). These problems coincided with the increasing cost of environmental regulation, making investment and development difficult. The Sodium Gluconate (1987-1995) cartel also suffered escalating production costs throughout the 1990s and from the fluctuating prices of the main raw material used in the production process, dextrose from corn (Mirasol 1998).

Fourthly, for some cartels, the problems outlined above were compounded by the Asia crisis in the late 1990s. The Animal Feed Vitamins cartel was particularly affected by the crisis as it already suffered from substantial overcapacity (Jarvis 2001). The Sorbates (1978-1996) cartel was coping with Chinese competition until a downturn in the market in 1996 coincided with the Asia crisis. This meant that Chinese sorbates originally destined for Asian markets were now flooding Europe and America at very low prices. Sorbates prices dropped from $\$ 4.25$ per pound in 1995 to less than $\$ 2$ per pound in 1999 (Jarvis 2000). Similarly the Food Flavouring (1989-1998) cartel 
collapsed because poor demand growth and increased capacity when there was already overcapacity, coincided with the Asia crisis. As a result prices collapsed from $€ 22-27$ in 1997 to €12-16 in 1999 and eventually €8-12 in 2000 (COMP/C.37.671 at 37).

Fifthly, some cartels failed because of relatively poor barriers to entry, unforeseen substitutability and distrust between the cartel members. The Amino Acids - Lysine (1990-1995) cartel is an example of this. In the late 1980s/early 1990s there was healthy demand growth in amino acids, prompting the incumbent producers (Ajinomoto, Daesang, Kyowa and Sewon) to increase capacity and form the cartel. However the market growth attracted new entrants ADM and Cheil who already had substantial operations in other parts of the chemical industry and so could easily switch to the production of amino acids. The entrance of ADM alone doubled capacity (COMP/36.545/F3 at 32). Amino acids suffer sharp demands shocks mainly because of their reliance on one industry: cereals. Once prices of amino acids started rising, the feed industry adjusted its production processes to accommodate less amino acids and more affordable substitutes, but keeping the same sets of nutritional values (COMP/36.545/F3 at 45). This was helped by the increasingly cheap availability of soybean meal and corn. ADM joined the cartel so as to avoid a price war but continued to increase its capacity. The cartel collapsed soon after the meeting of 19 May 1994 when the firms failed to reach agreement amid suspicions that ADM had been cheating the cartel (COMP/36.545/F3 at 360). Prices of amino acids had actually fallen during the cartel due to the increases in capacity and fall in demand. The demise of the Organic Peroxides cartel was also in part due to buyers slowly displacing its product with substitutes (Shearer 1996). In the cases of Citric Acid and Food Flavouring the pressures of Chinese competition and the Asia crisis forced firms to start cheating the cartel with its collapse occurring amidst distrust and resentment (e.g. COMP/E-1/36 604 at 118).

Finally, Mergers, acquisitions and restructuring in the industry put pressure on cartels as the identities and capacities of the players constantly changed. An example of this is MCAA Chemicals (1984-1999). This cartel involved monochloracetic acid, the market for which was in steady decline, but no serious competition existed from Asia. The cartel ended when an outside firm, Clariant, acquired Hoechst's MCAA business in 1997, and blew the whistle on that cartel receiving immunity in return (Wood 2005). 
The remarkable thing about the close relationship between the 11 cartels in the chemicals industry and the causes of their collapse is that yet more closely connected cartels are still being uncovered involving the 'usual suspects'. Currently the European Commission is investigating at least two: the first involves the price fixing of Hydrogen Peroxide in which 18 firms are involved including Solvay (involved in the Vitamins cartel) and Akzo Nobel (involved in MCAA Chemicals, Animal Feed Vitamins, Sodium Gluconate and Organic Peroxides cartels). The second concerns Methyl Methacrylate (Acrylic Plastics) and involves BASF (involved in Vitamins and Animal Feed Vitamins cartels). Furthermore both involve Arkema (formerly Atofina, involved in MCAA Chemicals and Organic Peroxides) and both were revealed through the leniency notice by Degussa, previously involved in Animal Feed Methionine and Organic Peroxides (Reisch 2005).

The findings of this section suggest that the cartels in the Chemical industry largely failed before they were revealed to the European Commission through leniency applications, casting doubt over claims that the 1996 leniency notice disrupted these cartels. However, the same cannot be said for the US Amnesty Program. Even though, we do not know exactly when all the US investigations started, we do know that investigations into Lysine and Christie's \& Sotheby's were opened by the DOJ well before these cartels ceased operating. However, we also know that in cases like Methylgucamine and Sorbates, as in Europe, investigations in the US were opened after the cartels had failed. Regardless of this, the conditions within the market will have strongly influenced a firm's decision to approach the DOJ or the European Commission with applications for leniency.

\section{Concluding Remarks}

Three quarters of the cartels brought to the Commission's attention under applications of the 1996 leniency notice were either previously or simultaneously under investigation by the U.S. DOJ, which exercises a more effective leniency programme for the reasons outlined earlier in this paper. In addition to this, 67\% of 1996 leniency notice success, in terms of fines imposed, concerned cartels which operated in just one industry. The close links between these cartels in the chemical industry, in 
addition to the market conditions of the 1990s meant that all 11 cartels had largely failed or ceased operating before an application for leniency was made. In light of this, the 1996 leniency notice did not play an instrumental role in inducing firms to reveal cartels to the extent suggested by Mario Monti's comments or by European Commission literature. Rather than inducing cartel members to reveal, the 1996 leniency notice largely helped to uncover cartels that had already failed because of US cartel policy success or because of market conditions or both. In this respect it has simply provided a way for firms to protect their own interests by seeking immunity from fines and possibly harming their former cartel partners by approaching the Commission after the cartel has failed and collusion has stopped - thus the leniency notice may have benefited collusion by taming the endgame for one of the players.

These findings are important because the 2002 leniency notice in place today is only a revised version of the original 1996 notice. The Commission made these adjustments to 'build on the success' of the 1996 notice and to make it more effective. However the findings of this paper raise the question of whether the leniency notice should be scrapped altogether, to give way to a new leniency programme designed from scratch. In particular, the reformed leniency system still suffers from inherent uncertainties for the firm wanting to reveal and has been described as a "one-sided poker game" (Joshua \& Camesasca 2005). The 2002 notice is broadly similar to the US Amnesty Program as reformed in 1993. However, the stakes are higher in the USA with the presence of a criminal offence for individuals, protection from treble damages, the existence of 'Amnesty Plus' and the use of the plea-bargaining system. Furthermore, it is unknown to what extent US amnesty applications have come as a result of cartels failing for factors unrelated to policy incentives as they have done in the chemical industry. The findings of this paper are also significant because many leniency programmes on the national EU member-state level are still based on the original 1996 leniency notice and, due to the slow pace of legislative change, many have not been reformed and so still contain some of the intrinsic weaknesses of the 1996 notice (Henry 2005). 


\section{References:}

ARBAULT, F. \& PEIRO, F., (DG COMP) 2002. The Commission's new notice on immunity and reduction of fines in cartel cases: building on success. EC Competition Policy Newsletter, No 2, June, p15.

BOSWELL, C., 2000. Upward Pricing Pressure for Organic Peroxides. Chemical Market Reporter Focus, May 15, p29.

CARLE, J., 2002. The New Leniency Notice. E.C.L.R. 23(6), 265-272.

CHAPMAN, K. \& EDMOND, H., 2000. Mergers / Acquisitions and Restructuring in the EU Chemical Industry: Patters and Implications. Regional Studies Vol 34.8, pp 753-767.

CONNOR, J. M., 2004. Extraterritoriality of the Sherman Act and Deterrence of Private International Cartels. (Working Paper) ExpressO Preprint Series, Paper 263.

HAMMOND, S. D., 2001. When calculating the costs and benefits of applying for Corporate Amnesty, how do you put a price tag on an individual's freedom? Speaking at Fifteenth Annual National Institute on White Collar Crime. The Westin St. Francis Hotel, San Francisco, CA. 8 March 2001.

HENRY, D., 2005. Leniency Programmes: An anaemic carrot for cartels in France, Germany and the UK. E.C.L.R. 26(1), p13-23.

HEWITT PATE, R., (US Department of Justice) 2004. International Anti-Cartel Enforcement. Speaking at the ICN Cartels Workshop, Sydney, Australia, November 21.

JARVIS, L., 2001. Choline Chloride Producers Attempt to Recapture Margins. Chemical Market Reporter, February 2.

JARVIS, L., 2000. Sorbates Could Stabilize with Exit of Two Players. Chemical Market Reporter, Vol. 260, p10.

JOSHUA, J. M. \& CAMESASCA, P. D., 2005. Where angels fear to tread: the Commission's 'new' leniency policy revisited. The European Antitrust Review 2005, p10.

MAHDI, S. et al, 2002. A Review of the Impact of Regulation on the Chemical Industry. Final Report to the Royal Commission on Environmental Pollution.

MIRASOL, F., 1998. Gluconate Prices moving up steadily as production costs continue escalating Chemical Market Reporter, Vol. 254, Issue 3, p5.

REISCH, M., 2005. European Commission probes cartel of Acrylic Plastics manufacturers. Chemical \& Engineering News, $29^{\text {th }}$ August, Vol. 83, Issue 3, p11.

SHEARER, B., 1996. Organic Peroxides Growing with the Plastics industry. Chemical Market Reporter, Vol. 249, Issue 17, p5. 
WILS, W., 2005. Is Criminalization of EU Competition Law the Answer? Speaking at the ACLE Conference on Remedies and Sanctions in Competition Policy, Amsterdam, Friday $17^{\text {th }}$ February 2005.

WOOD, A., 2005. Getting in a Fix. Chemical Week, Vol. 167, Issue 4, p5.

COMMISSION DECISIONS relating to a proceeding pursuant to Article 81 of the EC Treaty and Article 53 of the EEA Agreement:

9 December 2004 - (Case No C.37.533 - Choline Chloride)

29 September 2004 - (Case COMP/C.37.750/B2 - Brasseries Kronenbourg Brasseries Heineken)

17 December 2002 - (Case COMP/C.37.671 - Flood flavour enhancers)

27 November 2002 - (Case COMP/E-2/37.978 - Methylglucamine)

20 December 2001 - (Case COMP/E-1/36.212 - Carbonless paper)

5 December 2001 - (Case No COMP/E-1/36 604 - Citric acid)

5 December 2001 - (Case IV/37.614/F3 — Interbrew and Alken-Maes)

21 November 2001 - (Case COMP/E-1/37.512 - Vitamins)

7 June 2000 - (Case COMP/36.545/F3 - Amino Acids) 